\title{
PROBLEMATYKA KSZTALTOWANIA ZRÓWNOWAŻONYCH SYSTEMÓW TRANSPORTOWYCH PERYFERYJNYCH OBSZARÓW MIAST NA PRZYKŁADZIE DZIELNICY PRZEMYSŁOWEJ METALCHEM W OPOLU
}

\section{STRESZCZENIE}

Zapewnienie efektywnego funkcjonowania systemów transportowych obszarów peryferyjnych w miastach bywa niejednokrotnie trudne, na co składa się wiele przyczyn. Celem artykułu jest przedstawienie wyników badań dotyczących poziomu zrównoważenia, w tym funkcjonalności, transportu w peryferyjnej dzielnicy przemysłowej Opola Metalchem, jak też ocena planów władz miasta co do zmian w systemie transportowym dzielnicy. Zdiagnozowane zostały główne elementy systemu transportowego oraz problemy związane z funkcjami, jakie na badanym obszarze powinien on pełnić. Następnie omówiono plany władz miasta dotyczące zmian w zagospodarowaniu dzielnicy, w tym przekształceń systemu transportowego. Ostatnia część opracowania zawiera ocenę planowanych działań władz Opola.

Słowa kluczowe: zrównoważony system transportowy, Metalchem, Opole

\section{Wprowadzenie}

Konieczność budowy zrównoważonych systemów transportowych stała się niezaprzeczalna $\mathrm{w}$ obliczu ogromnej roli, jaką transport pełni z punktu widzenia rozwoju społeczno-gospodarczego, a jednocześnie wskutek negatywnych efektów

\footnotetext{
*Adres e-mail: mparadowska@uni.opole.pl.
} 
zewnętrznych, jakie generuje, obniżając tym samym wydajność gospodarki, jakość życia społeczeństw oraz szkodząc środowisku i ekosystemom. Celem artykułu jest ocena poziomu zrównoważenia, w tym funkcjonalności, transportu w peryferyjnej dzielnicy przemysłowej Opola Metalchem. W pierwszej kolejności zdiagnozowane zostały główne elementy systemu transportowego oraz problemy związane z funkcjami, jakie na badanym obszarze powinien on pełnić. Następnie omówiono plany władz miasta dotyczące zmian w zagospodarowaniu dzielnicy, w tym przekształceń systemu transportowego. Ostatnia część opracowania zawiera ocenę planowanych działań władz Opola.

\section{Cechy i funkcje zrównoważonego systemu transportowego}

Właściwości zrównoważonego systemu transportowego zostały zdefiniowane w sposób bardziej szczegółowy po raz pierwszy w ramach OECD w 1996 r. ${ }^{1}$, a następnie przez grupę ekspertów w ramach Komisji Europejskiej w 1999 r. $^{2}$ Obie definicje podkreślały funkcje, jakie transport powinien pełnić z punktu widzenia celów społeczno-gospodarczych, a jednocześnie wskazywały na konieczność zmniejszenia jego presji na środowisko. Liczne badania dotyczące zrównoważonych systemów transportowych potwierdzają znaczenie omawianego zagadnienia $^{3}$. Podstawowe cechy zrównoważonego systemu transportowego zostały przedstawione w tabeli 1.

Przedstawiona w niniejszym opracowaniu analiza dzielnicy Metalchem w Opolu ma charakter cząstkowy i nie uwzględnia wszystkich właściwości zrównoważonego systemu transportowego. Wynika to $\mathrm{z}$ faktu, iż badania koncentrowały się głównie na funkcjonalności transportu z punktu widzenia mieszkańców oraz przedsiębiorstw zlokalizowanych na analizowanym obszarze, a także poziomu najbardziej uciążliwych negatywnych efektów zewnętrznych transportu.

${ }^{1}$ OECD Proceedings Towards Sustainable Transportation, The Vancouver Conference. Conference highlights and overview of issues, OECD, Vancouver 1996, s. 12.

2 Defining an Environmentally Sustainable Transport System, Commission Expert Group on Transport and Environment 2000, s. 5.

${ }^{3}$ Zob. m.in. Keeping Our Cities Moving. EU Research for Sustainable Urban Development and Land Use, European Commission 2004, http://ec.europa.eu/research/environment/pdf/mob_move en.pdf (24.06.2015); Transport Research and Innovation Centre, http://www.transport-research.info/ web/ (24.06.2015). 
Tabela 1. Właściwości zrównoważonego systemu transportowego

\begin{tabular}{|c|c|}
\hline $\begin{array}{l}\text { Podstawowe sfery } \\
\text { zrównoważonego } \\
\text { rozwoju }\end{array}$ & Zrównoważony system transportowy \\
\hline $\begin{array}{c}\text { Sfera } \\
\text { środowiskowa }\end{array}$ & $\begin{aligned} \text { - funkcjonuje w sposób bezpieczny, nie zagrażając ludziom ani ekosyste- } \\
\text { mom } \\
\text { - } \text { ogranicza koszty zewnętrzne w ramach zdolności absorpcyjnych planety } \\
\text { - ogranicza energochłonność oraz terenochłonność } \\
\text { - } \text { wykorzystuje surowce odnawialne poniżej ich możliwości tworzenia, } \\
\text { a nieodnawialne na lub poniżej poziomu ich odnawialnych substytutów }\end{aligned}$ \\
\hline $\begin{array}{c}\text { Sfera } \\
\text { ekonomiczna }\end{array}$ & 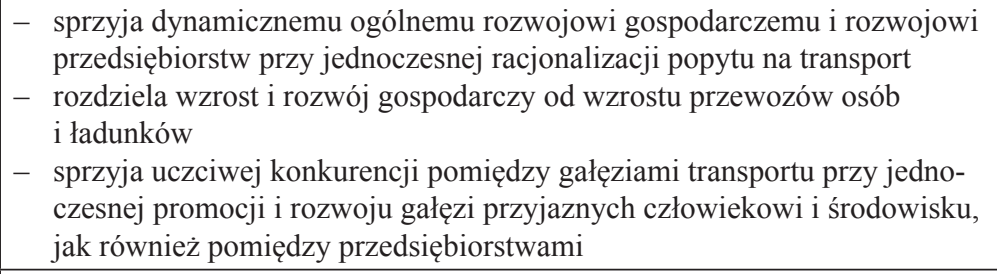 \\
\hline $\begin{array}{c}\text { Sfera } \\
\text { społeczna }\end{array}$ & $\begin{array}{l}\text { - zapewnia dostępność funkcjonalną i finansową } \\
\text { - oferuje możliwość wyboru gałęzi transportu przy jednoczesnym upo- } \\
\text { wszechnianiu zrównoważonych zachowań komunikacyjnych użytkowni- } \\
\text { ków } \\
\text { - } \\
\text { sprzyja rozwojowi jednostek i społeczeństw przy jednoczesnej racjonaliza- } \\
\text { cji popytu na transport } \\
\text { - zapewnia równość między obecnymi i przyszłymi pokoleniami } \\
\text { - wpływa na podnoszenie jakości życia }\end{array}$ \\
\hline
\end{tabular}

Źródło: M. Paradowska, Rozwój zrównoważonych systemów transportowych polskich miast i aglomeracji w procesie integracji z Unia Europejska - przyktad aglomeracji wroctawskiej, Wydawnictwo Uniwersytetu Opolskiego, Opole 2011, s. 312-313.

\section{Charakterystyka systemu transportowego dzielnicy Metalchem w Opolu}

Metalchem nie stanowi oficjalnej nazwy analizowanej dzielnicy, lecz wywodzi się z przemysłowej tradycji obszaru i funkcjonującej tam w czasach socjalizmu fabryki chemikaliów. Obecnie na terenie przemysłowym funkcjonuje kilkanaście dużych i kilka mniejszych przedsiębiorstw, które z własnej inicjatywy utworzyły stowarzyszenie Park Przemysłowy Metalchem ${ }^{4}$ a spora część działek czeka na kolejnych inwestorów. Z kolei wybudowane na potrzeby fabryki bloki mieszkalne dla

\footnotetext{
${ }^{4}$ Firmy z Metalchemu biora sprawy w swoje ręce, http://www.24opole.pl/14367,Firmy_z_Metalchemu_biora_sprawy_w_swoje_rece,wiadomosc.html (30.04.2015).
} 
pracowników przekształciły się samoistnie w dwa peryferyjne osiedla dla ponad 3 tys. mieszkańców. Sąsiadują one z dość dużym nieużytkownym terenem, a dodatkowo w dzielnicy stale powiększa się osiedle domów jednorodzinnych.

Pierwszorzędna rola transportu na analizowanym obszarze wynika z potrzeb mieszkańców osiedli oraz zlokalizowanych na terenie przemysłowym przedsiębiorstw. System transportowy powinien umożliwić sprawne dotarcie do szkoły, pracy, ale także zapewnić dostępność różnego rodzaju usług i handlu, stąd istotne jest skomunikowanie z centrum Opola. W odniesieniu do przedsiębiorstw znaczenie ma obsługa zaopatrzenia i dystrybucji, jak i dojazdy pracowników czy klientów biznesowych. Tu liczy się skomunikowanie z głównymi węzłami transportowymi regionu. $\mathrm{Z}$ punktu widzenia potrzeb miasta i regionu istotny jest też tranzytowy ruch w kierunku Opole-Kędzierzyn-Koźle.

\section{Rysunek 1. Poglądowa mapa dzielnicy Metalchem}

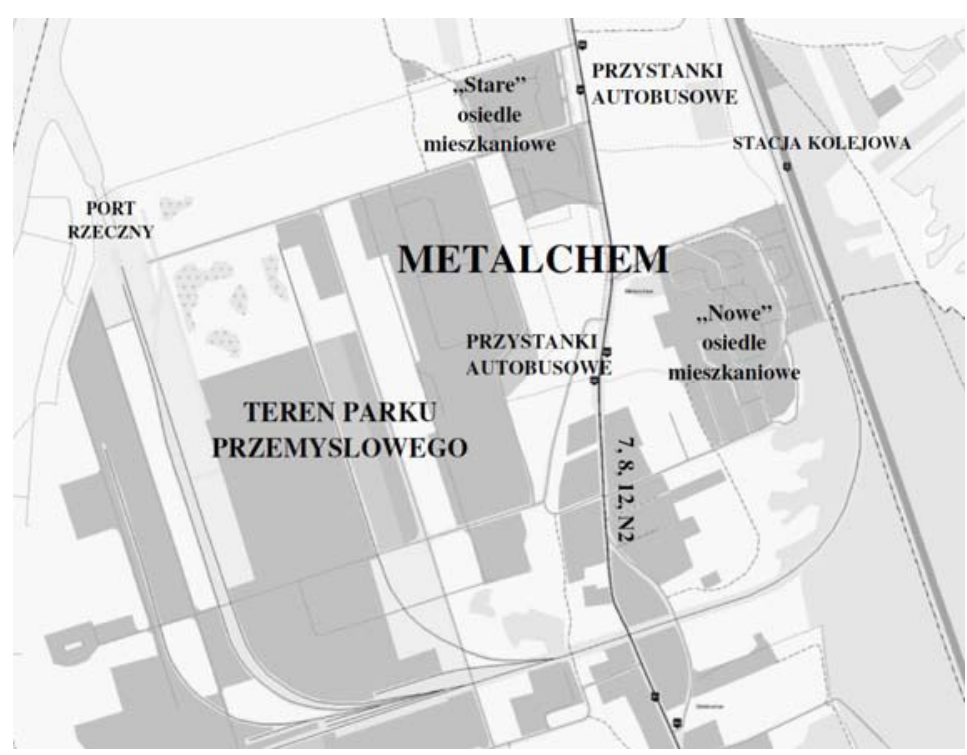

Źródło: opracowanie własne przy użyciu: OWI, Opolskie w Internecie, Mapy Opolskie, http:// maps.opolskie.pl/ogis/Default.aspx?gpw=f1b7cc34-82e3-4763-b5ac-d1b3c9aea5b2 (30.11.2014).

W ramach systemu transportowego opisywanego obszaru dostępne są niemal wszystkie gałęzie i rodzaje transportu. Mieszkańcy i pracownicy przedsiębiorstw 
mogą korzystać z transportu drogowego, kolejowego, a także komunikacji miejskiej, zaś przedsiębiorstwa z transportu drogowego, kolejowego i żeglugi śródlądowej. Główna oś transportowa wyznaczona jest przez drogę wojewódzką nr 423 (tu: ul. Oświęcimska) łączącą Metalchem zarówno z centrum Opola, jak i z autostradą A4 w kierunku południowym, a także przez linię kolejową nr 136 łączącą Opole Groszowice oraz Kędzierzyn-Koźle. Niewielka stacja kolejowa Grotowice położona jest za większym, nowym osiedlem, zaś spośród kilku bocznic kolejowych na terenie przemysłowym tylko jedna jest użytkowana i utrzymywana w dobrym stanie technicznym. Stanowi ona własność przedsiębiorstwa, które nabyło również i wyremontowało port rzeczny przeznaczony głównie do transportu wyrobów wielkogabarytowych. Nie wliczając ruchu tranzytowego na drodze wojewódzkiej, podstawowymi generatorami ruchu na badanym obszarze są przedsiębiorstwa zlokalizowane w parku przemysłowym oraz obydwa osiedla, ale też np. supermarket, przedszkole czy kościół. Poglądowa mapa badanego obszaru została przedstawiona na rysunku 1.

\section{Ocena funkcjonalności systemu transportowego dzielnicy Metalchem w Opolu ${ }^{5}$}

Analiza systemu transportowego badanej dzielnicy pozwala wskazać na kilka problemów istotnych z punktu widzenia jego funkcjonalności i poziomu zrównoważenia. Przede wszystkim ul. Oświęcimska to jedyne połączenie drogowe analizowanego obszaru z centrum Opola, jak i wyprowadzające ruch poza miasto w kierunku autostrady A4. Trudności wynikające z braku alternatywy potęguje wspólne wykorzystywanie drogi przez mieszkańców, przedsiębiorstwa i ruch tranzytowy. Rezultaty to głównie duże natężenie ruchu w godzinach szczytu, pogarszanie się stanu technicznego drogi, a także swoiste konflikty pomiędzy sferą mieszkaniową i przemysłową - np. mniejsze poczucie bezpieczeństwa na drodze, przejściach dla pieszych, trudności z wyjazdem z dróg podporządkowanych, relatywnie duże natężenie hałasu i drgań wynikających z ruchu ciężarowego (przyczyniających się do pękania ścian budynków) i zanieczyszczenia powietrza. Wszystko to prowadzi do obniżenia jakości życia mieszkańców badanej dzielnicy.

\footnotetext{
${ }^{5}$ Informacje zawarte $\mathrm{w}$ tym punkcie oparte są na wynikach badań opublikowanych w raporcie z grantu badawczego realizowanego na zlecenie Prezydenta Miasta Opola jesienią 2014 r. pt. „Analiza gospodarcza oraz przestrzenna wraz z elementami analizy społecznej części obrębów ewidencyjnych Groszowic i Grotowic, w tym parku przemysłowego «Metalchem»". Raport ten zawiera szczegółowe dane statystyczne, dane pochodzące z dokumentów źródłowych, a także uzyskane podczas badań własnych, stanowiące podstawę wniosków przedstawionych w tej części artykułu.
} 
Większość firm z terenu przemysłowego wykorzystuje jedynie transport drogowy. Pod kilkoma względami system transportowy parku przemysłowego nie jest w pełni zrównoważony. W pierwszym rzędzie system dróg wewnętrznych cechują niezadowalające parametry techniczne z punktu widzenia ruchu ciężarowego, ponadto niektóre odcinki nie są dostosowane do przewozu towarów wielko- i ponadgabarytowych, czego wymaga specyfika produkcji niektórych przedsiębiorstw. Zły stan techniczny dróg i brak oświetlenia to też uciążliwości dla kierowców samochodów osobowych, rowerzystów i pieszych. Dużym mankamentem jest słaba dostępność (odległość ponad jednego kilometra) przystanków autobusowych dla pracowników przedsiębiorstw położonych w najgłębszej części parku.

Podobnie niezadowalająca jest istniejąca $\mathrm{w}$ dzielnicy infrastruktura pieszo-rowerowa. Jedyny udostępniony ciąg pieszo-rowerowy nie znajduje kontynuacji w ścieżkach w kierunku centrum i poza granice Opola. Powoduje to niespójność całego systemu ścieżek rowerowych, zniechęca do wykorzystania roweru oraz powoduje zmniejszenie bezpieczeństwa rowerzystów. Dodatkowo niespójna i niewystarczająca (zwłaszcza na terenach osiedli i parku przemysłowego) infrastruktura piesza nie jest dostatecznie przystosowana do potrzeb użytkowników o specjalnych potrzebach. Zastrzeżenia budzi też m.in. niezadowalające oświetlenie niektórych odcinków dróg, chodników i przejść dla pieszych.

W kontekście funkcjonowania miejskiej komunikacji autobusowej największym mankamentem wydaje się być wspomniana bardzo słaba dostępność przystanków dla pracowników niektórych przedsiębiorstw. Pozostałe problemy dotyczą głównie zbyt małej częstotliwości kursów, trudności w zakupie biletów czy nieodpowiedniego zachowania kierowców. Istotną rolę odgrywa również brak ułatwień czy priorytetów dla autobusów oraz konieczność współużytkowania tej samej drogi z pozostałymi pojazdami.

Natomiast stacja Grotowice i połączenia kolejowe nie stanowią atrakcyjnej alternatywy ani dla mieszkańców, ani dla pracowników - niemal nikt z nich nie korzysta. Wynikać to może ze złego stanu i zdewastowania stacji, a także jej izolacji w stosunku do osiedli, bardzo słabej dostępności z punktu widzenia pracowników przedsiębiorstw, jak też niskiego poczucia bezpieczeństwa. Istniejące bariery architektoniczne uniemożliwiają w zasadzie korzystanie z niej przez osoby niepełnosprawne. Brak jakiegokolwiek oznakowania lokalizacji stacji sprawia, że jej odna- 
lezienie jest kłopotliwe. Na to nakłada się też mniejsza dostępność cenowa połączeń kolejowych w porównaniu do komunikacji autobusowej.

Jak już wspomniano, zarówno jedyna czynna bocznica kolejowa, jak i port rzeczny na obszarze parku przemysłowego stanowią własność jednego przedsiębiorstwa i są głównie wykorzystywane właśnie przez nie ze względu na specyfikę produkowanych wyrobów. Niemniej jednak w razie potrzeby przedsiębiorstwo udostępnia je innym firmom. Główne problemy z punktu widzenia funkcjonalności tych gałęzi transportu wiążą się w większym stopniu z polityką krajową i europejską, a zatem wychodzą poza zakres niniejszego opracowania.

Podsumowując, należy podkreślić, że system transportowy badanego obszaru wymaga przekształceń zapewniających jego większy poziom zrównoważenia, zwłaszcza pod kątem zwiększenia atrakcyjności wskazanych aspektów transportu publicznego, poprawy infrastruktury pieszej i rowerowej oraz ograniczenia uciążliwości wynikających z dużego natężenia ruchu drogowego.

\section{Plany zmian w zagospodarowaniu dzielnicy}

Jesienią 2014 r. władze Opola wyłożyły do publicznego wglądu nowo opracowany projekt miejscowego planu zagospodarowania przestrzennego dzielnicy Metalchem, który ostatecznie po nielicznych zmianach został uchwalony w styczniu 2015 r. ${ }^{6}$ Przeobrażenia, którym ma zostać poddane zagospodarowanie terenu, dotyczą w głównej mierze systemu transportowego. Przede wszystkim dotychczasowe nieużytki wraz z częścią nieurządzonych terenów zielonych położonych na terenie obszaru przemysłowego mają zostać przekształcone w ogromny węzeł komunikacyjny oddzielający nowe osiedle od parku przemysłowego oraz starego osiedla. Droga wojewódzka ma zostać poprowadzona od tego węzła równolegle do ul. Oświęcimskiej, lecz na terenie przemysłowym, zaś część ul. Oświęcimskiej ma zyskać klasę drogi lokalnej. W efekcie oba osiedla położone mają być przy węźle transportowym, co związane jest z przebiegiem planowanej i uwzględnionej w planach miasta ${ }^{7}$ obwodnicy wschodniej i połączeniem jej z tzw. trasą odrzańską, której integralną część

${ }^{6}$ Uchwała nr VI/53/15 Rady Miasta Opola z 29 stycznia 2015 r. w sprawie uchwalenia miejscowego planu zagospodarowania przestrzennego „Metalchem” w Opolu.

7 Studium uwarunkowań i kierunków zagospodarowania przestrzennego Miasta Opola, uchwała nr LXXI/745/10 Rady Miasta Opola z 26 sierpnia 2010 r. 
stanowi droga wojewódzka nr 423. Co więcej, węzeł komunikacyjny ma być wielopoziomowy i przebiegać będzie w bezpośredniej bliskości budynku mieszkalnego starego osiedla oraz w bliskim sąsiedztwie nowego osiedla. Przy wjeździe na teren parku przemysłowego utworzona ma zostać pętla autobusowa, zaś zmiany w systemie dróg na obszarze parku przemysłowego mają umożliwić wprowadzenie tam miejskiej komunikacji autobusowej. Przekształceniom systemu dróg towarzyszyć ma budowa spójnego - przynajmniej na obszarze objętym planem - systemu ścieżek rowerowych. W uchwalonym miejscowym planie zagospodarowania przestrzennego odrzucono szereg zmian sugerowanych przez różnych interesariuszy, w tym zmiany dotyczące przesunięcia lokalizacji węzła komunikacyjnego, tak aby zmniejszyć powstałe w wyniku jego budowy uciążliwości dla strefy mieszkaniowej.

\section{Dyskusja i wnioski}

Uwzględniając obecną funkcjonalność systemu transportowego dzielnicy Metalchem z punktu widzenia jego użytkowników, a także wymogi zrównoważonego rozwoju transportu, niezbędne przekształcenia na analizowanym obszarze musiałyby w pierwszym rzędzie prowadzić do minimalizacji problemów powstających wskutek współużytkowania systemu drogowego przez mieszkańców, przedsiębiorstwa i ich pracowników oraz ruch tranzytowy. Byłoby to możliwe dzięki wyprowadzeniu ruchu ciężarowego z ul. Oświęcimskiej na odcinku od starego osiedla w kierunku Grotowic poprzez budowę drogi łączącej Park Przemysłowy Metalchem z głównymi węzłami drogowymi, jak również budowę obwodnicy miasta w wariancie przebiegu umożliwiającym skomunikowanie z drogami wojewódzkimi, krajowymi i autostradą A4. Jednak jednocześnie należałoby zapewnić zminimalizowanie kosztów zewnętrznych transportu poprzez zapewnienie odpowiedniej odległości nowych elementów systemu transportowego od terenów mieszkaniowych i/lub odizolowanie ich np. pasami zieleni czy barierami dźwiękochłonnymi. Tymczasem uchwalony plan miejscowy przedkłada rozbudowę sieci drogowej w celu odciążenia centrum Opola kosztem mieszkańców analizowanej dzielnicy peryferyjnej, co przyczyni się dodatkowo do wzmożenia ruchu tranzytowego. Podjęta decyzja wydaje się być forsowaniem najłatwiejszego bądź jednego z najłatwiejszych wariantów.

\footnotetext{
${ }^{8}$ Uchwała nr VI/53/15 Rady Miasta Opola z 29 stycznia 2015 r. w sprawie uchwalenia miejscowego planu zagospodarowania przestrzennego „Metalchem” w Opolu, s. 271.
} 
W efekcie budowa węzła spowoduje przestrzenną izolację obu osiedli, zmniejszy wzajemną dostępność usług i handlu zlokalizowanych na ich terenach, stworzy dodatkowe lokalne bariery komunikacyjne i wzmocni natężenie negatywnych efektów zewnętrznych transportu.

Za pozytywne rozwiązania należy uznać wprowadzenie komunikacji autobusowej na teren parku przemysłowego oraz budowę ścieżek rowerowych. Nie jest jednak pewne, czy całościowo zwiększy się atrakcyjność transportu publicznego i rowerowego na danym obszarze ze względu na nierozpoznane działania władz dotyczące rozwiązań na pozostałych odcinkach systemu transportowego (zwłaszcza w kierunku centrum Opola).

\section{Podsumowanie}

Rozwiązania uchwalone w planie miejscowym nie przyczynią się kompleksowo do zwiększenia funkcjonalności i poziomu zrównoważenia systemu transportowego obszaru. Swego rodzaju beneficjentami staną się przedsiębiorstwa dzięki bezpośredniej bliskości obwodnicy wschodniej miasta i węzła transportowego, a także większej dostępności komunikacji autobusowej dla pracowników, ale też dla mieszkańców domów jednorodzinnych przy odcinku ul. Oświęcimskiej przekształconej w drogę lokalną. Natomiast jakość życia mieszkańców nowego i starego osiedla pogorszy się, co można interpretować jako marginalizowanie i niejako lekceważenie funkcji mieszkaniowej przez władze miasta. Faworyzowany zdaje się być transport drogowy, interes większości użytkowników całego systemu transportu drogowego miasta i regionu oraz efekty gospodarcze (interes przedsiębiorstw zlokalizowanych w parku przemysłowym) kosztem lokalnej sfery społecznej.

\section{Literatura}

Defining an Environmentally Sustainable Transport System, Commission Expert Group on Transport and Environment 2000.

Firmy z Metalchemu biora sprawy w swoje ręce, http://www.24opole.pl/14367,Firmy_ z_Metalchemu_biora_sprawy_w_swoje_rece,wiadomosc.html.

Keeping Our Cities Moving. EU Research for Sustainable Urban Development and Land Use, European Commission 2004, http://ec.europa.eu/research/environment/pdf/mob_ move_en.pdf. 
OECD Proceedings Towards Sustainable Transportation, The Vancouver Conference. Conference highlights and overview of issues, OECD, Vancouver 1996.

OWI, Opolskie w Internecie, Mapy Opolskie, http://maps.opolskie.pl/ogis/Default. aspx?gpw=f1b7cc34-82e3-4763-b5ac-d1b3c9aea5b2.

Paradowska M., Rozwój zrównoważonych systemów transportowych polskich miast $i$ aglomeracji $w$ procesie integracji z Unia Europejska - przykład aglomeracji wrocławskiej, Wydawnictwo Uniwersytetu Opolskiego, Opole 2011.

Studium uwarunkowań i kierunków zagospodarowania przestrzennego Miasta Opola, uchwała nr LXXI/745/10 Rady Miasta Opola z 26 sierpnia 2010 r.

Szafranek E., Paradowska M., Klimek R., Dembicka-Niemiec A., Analiza gospodarcza oraz przestrzenna wraz z elementami analizy społecznej części obrębów ewidencyjnych Groszowic $i$ Grotowic $w$ tym parku przemystowego Metalchem, opracowanie na zlecenie Urzędu Miasta Opola realizowanego w ramach Programu „Grant Naukowy Prezydenta Miasta Opola”, Opole 2014.

Transport Research and Innovation Centre, http://www.transport-research.info/web/.

Uchwała nr VI/53/15 Rady Miasta Opola z 29 stycznia 2015 r. w sprawie uchwalenia miejscowego planu zagospodarowania przestrzennego „Metalchem” w Opolu.

\title{
PROBLEMS OF CREATING SUSTAINABLE TRANSPORT SYSTEMS IN PERIPHERAL URBAN AREAS - A CASE OF INDUSTRIAL DISTRICT METALCHEM IN OPOLE
}

\begin{abstract}
Ensuring the efficiency of transport systems of the peripheral urban areas is most often difficult. The aim of the paper is to present research results on the functionality of the transport system in an industrial district Metalchem in Opole, including requirements of sustainable transport development, as well as to assess the plans of the municipalities regarding changes in the local transport system. First, main elements of the transport system and key transport roles in the area were diagnosed. Then, actions planned by the local authorities to be taken in terms of changes in the transport system were elaborated. In the last part of the paper an attempt was made to evaluate the measures planned in the context of requirements of sustainable transport development as well as of transport needs of the system's users.
\end{abstract}

Keywords: sustainable transport system, Metalchem, Opole

JEL Codes: R41, R42, Q01 